Agric. Biol. Chem., 41 (9), 1567 1574, 1977

\title{
Purification and Properties of Lysophospholipase Produced by Corticium centrifugum ${ }^{\dagger}$
}

\author{
Satoshi Uehara, Kiyozo Hasegawa, ${ }^{* 1}$ Mikiro Tada, ${ }^{* 2}$ \\ Michiyo Murata, Tetsuya Suzuki and Kazuo IwaI*3 \\ Research Institute for Food Science, Kyoto University, Uji, \\ Kyoto 611, Japan
}

Received November 8, 1976

\begin{abstract}
Lysophospholipase (EC 3.1.1.5) from the culture broth of Corticium centrifugum was purified 92-fold in specific activity by DEAE-Sephadex and hydroxylapatite column chromatography. The isoelectric point was at about $\mathrm{pH} 3.9$, and the molecular weight was about 130,000. The optimal $\mathrm{pH}$ was about 3.5 5.0. The stable $\mathrm{pH}$ range was from 7.0 to 8.0 . Lysophospholipase activity was inhibited by $\mathrm{Fe}^{3+}, \mathrm{Hg}^{2+}$ and $\mathrm{Al}^{3+}$, but stimulated by various organic solvents. Diazobenzene $p$-sulfonic acid, N-bromosuccinimide and diisopropylfluorophosphate also inhibited the activity. This enzyme did not hydrolyze mono-, di- or tripalmitin or phosphatidylcholine. Apparent Michaelis constants of lysophospholipase activity for 1-acyl-LPC, 1-palmitoyl-LPC and 1-oleoyl-LPC were $0.35,0.16$ and $0.09 \mathrm{~mm}$, respectively. The effect of detergents on the enzyme activity was observed to differ with the fatty acid composition of substrate.
\end{abstract}

It has previously been demonstrated that phospholipids acyl-hydrolases are present in the cell wall lytic enzyme preparation from Corticium centrifugum. ${ }^{12}$ To make clear the properties of and relations among various phospholipids acyl-hydrolases, i.e., phospholipases $\mathrm{A}$ and $\mathrm{B}$ and lysophospholipase, we attempted to purify the lysophospholipase of this sample at first. In this paper, purification of this enzyme and its properties are described.

\section{MATERIALS AND METHODS}

Enzyme. A lyophilized crude enzyme preparation was prepared from the culture broth of $C$. centrifugum

$\uparrow$ A part of this paper was presented at the Annual Meeting of the Agricultural Chemical Society of Japan, Sapporo, July 25, 1975.

*1 Present address: Nara Women's University, Nara, Japan.

*2 On leave from Okayama University.

*3 To whom reprint requests should be addressed.

Abbreviations: PC, phosphatidylcholine; LPC, lysophosphatidylcholine; FFA, free fatty acid; PCase, phosphatidylcholine acyl-hydrolase; LPCase, lysophospholipase; TLC, thin-layer chromatography; PPO, 2, 5-diphenyloxazole; POPOP, 1, 4-bis [2-(5-phenyloxazolyl)]-benzene. as follows. The mold was cultured in a medium, consisting of $4 \%$ of heat-treated brewer's yeast, $0.1 \%$ of $\mathrm{KH}_{2} \mathrm{PO}_{4}, 0.05 \%$ of $\mathrm{KCl}, 0.05 \%$ of $\mathrm{MgSO}_{4} \cdot 7 \mathrm{H}_{2} \mathrm{O}$ and $0.001 \%$ of $\mathrm{FeSO}_{4} \cdot 7 \mathrm{H}_{2} \mathrm{O}$, at $26 \sim 28^{\circ} \mathrm{C}$ for $67 \sim 93 \mathrm{hr}$. The culture broth was filtered through two layers of cheese cloth and pulp layer, followed by ultrafiltration. The precipitate from the concentrated culture filtrate obtained by saturation with ammonium sulfate was collected and dialyzed against water for only $4 \mathrm{hr}$ (because of the damage of the cellulose tubing by a cell wall lytic activity in the culture filtrate), followed by lyophilization. The purification of this crude enzyme preparation was done twice. The respective purified enzyme preparations were numbered I and II, of which specific activities were 68.0 and 50.9 units $/ \mathrm{mg}$, respectively. One unit of activity was defined as the quantity of enzyme which liberated $1 \mu$ mole of fatty acid per min.

Substrate. PC was prepared from egg yolk by the method of Pangborn, ${ }^{2)}$ and was purified by silicic acid column chromatography. LPC was prepared by the action of Vipera russelli phospholipase A (Sigma Chem. Co.) or Crotalus adamanteus phospholipase A (Worthington Biochem. Co.) on PC by the procedure of Hanahan, ${ }^{3)}$ and purified by silicic acid column chromatography. (u)-[14 C]-1-Acyl-LPC was prepared by the action of Vipera russelli phospholipase $A$ on (u) $-\left[{ }^{14} \mathrm{C}\right]-$ PC (New England Nuclear Co.) which was diluted with unlabeled PC from egg yolk previously. 1-[ $\left.{ }^{14} \mathrm{C}\right]-$ Palmitoyl-LPC was prepared by the action of Crotalus adamanteus (Sigma Chem. Co.) phospholipase A on 
L- $\alpha$-dipalmitoyl-1- $\left[{ }^{14} \mathrm{C}\right]$-phosphatidylcholine (Applied Science Laboratories Inc.) which was diluted with unlabeled dipalmitoylphosphatidylcholine (Serdary Research Laboratories) previously. $1-\left[{ }^{14} \mathrm{C}\right]$-OleoylLPC was prepared by the same method as described above from L- $\alpha$-dioleoyl-1- $\left[{ }^{14} \mathrm{C}\right]$-phosphatidylcholine (Applied Science Laboratories Inc.) which was diluted with unlabeled dioleoylphosphatidylcholine (Serdary Research Laboratories). These LPCs were purified by silicic acid column chromatography. The specific radioactivities of (u)-[ $\left[{ }^{14} \mathrm{C}\right]-1$-acyl-LPC, $1-\left[{ }^{14} \mathrm{C}\right]-$ palmitoyl-LPC and 1-[ $\left.{ }^{14} \mathrm{C}\right]$-oleoyl-LPC were 30,45 and 95 $\mathrm{cpm} / \mathrm{m} \mu$ mole LPC, respectively.

Enzyme assay. LPCase activity, when unlabeled LPC was used as substrate, was assayed as follows. The reaction mixture contained $0.5 \mathrm{ml}$ of aqueous solution of LPC ( $2 \mu$ moles), $1.2 \mathrm{ml}$ of $0.1 \mathrm{M}$ acetate buffer, $\mathrm{pH} 4.0$, and $0.3 \mathrm{ml}$ of enzyme solution in a total volume of $2 \mathrm{ml}$. Incubation was carried out at $30^{\circ} \mathrm{C}$ for 8 min with shaking at a rate of 120 times per min. The reaction was stopped by addition of 2.5 volumes of methanol and by heating at $80^{\circ} \mathrm{C}$ for $1 \mathrm{~min}$. The products were partitioned between chloroform and aqueous methanol by the procedure of Bligh and Dyer. ${ }^{4}$ ) Enzyme activity was assayed by measuring FFA liberated in the chloroform phase by the method of Duncombe, ${ }^{(5)}$ Satouchi et al. ${ }^{8)}$ and Itaya et al., ${ }^{7)}$ with palmitic acid as standard. In some cases in which enzyme preparation I was used, incubation was carried out in $0.1 \mathrm{M}$ acetate buffer, $\mathrm{pH} 3.6$, at $45^{\circ} \mathrm{C}$.

For assay of PCase, $0.5 \mathrm{ml}$ of ultrasonic dispersion of PC ( $2 \mu$ moles), which was sonicated with an ultrasonic oscillator (Kaijo Denki Model 4251S), $10 \mathrm{KHz}$, for $1 \mathrm{~min}$, was used as substrate in place of aqueous solution of LPC. Other conditions and procedures were the same as above.

When labeled LPC was used as substrate, the reaction mixture contained LPC ( $1 \mu$ mole) which was pipetted in the reaction tube as methanol solution and evaporated, $0.9 \mathrm{ml}$ of $0.1 \mathrm{M}$ acetate buffer, $\mathrm{pH} 4.0$, and $0.1 \mathrm{ml}$ of enzyme solution in a total volume of $1 \mathrm{ml}$. Enzyme reaction was carried out at $30^{\circ} \mathrm{C}$ for $8 \mathrm{~min}$. The reaction was stopped by addition of 2.5 volumes of methanol and by heating at $80^{\circ} \mathrm{C}$ for $1 \mathrm{~min}$. After the reaction, the products were partitioned between chloroform and aqueous methanol by the procedure of Bligh and Dyer, ${ }^{4)}$ and $2 \mathrm{ml}$ of the chloroform phase was concentrated and spotted on Silica gel $G$ plates (Merck). After TLC, each fraction of FFA, PC and LPC was scraped off, and its radioactivity was countered in a Packard 2425 liquid scintillation spectrometer with $10 \mathrm{ml}$ of scintillation mixture containing $0.1 \mathrm{~g}$ of POPOP and $4 \mathrm{~g}$ of PPO per liter of toluene.

Thin-layer chromatography. The reaction products in the chloroform phase were analyzed by thin-layer chromatography, using silica gel plates (Merck) with chloroform-methanol-water $(80: 35: 5, \mathrm{v} / \mathrm{v})$ as solvent. Spots were visualized by iodine vapor.

Isoelectric focusing. Isoelectric focusing was carried out in a $30 \mathrm{ml}$ apparatus devised by Doi et al., ${ }^{8)}$ in accordance with the method of Vesterberg. ${ }^{9)}$ Electrophoresis was performed with a carrier of $\mathrm{pH} 2.5 \sim 6.0$ at $500 \sim 800 \mathrm{~V}(0.5 \sim 1.0 \mathrm{~mA})$ for $50 \mathrm{hr}$ at $0 \sim 4^{\circ} \mathrm{C}$. After the electrophoretic run, the ampholine solution was fractionated to $1 \mathrm{ml}$, followed by measurment of $\mathrm{pH}$ and activity.

Determination of protein concentration. Protein concentration was determined by the method of Lowry et al. ${ }^{10)}$ with bovine serum albumin as standard.

Disc electrophoresis. Disc electrophoresis was conducted in $7.5 \%$ gel for 90 min with a current of $2 \mathrm{~mA} /$ tube at $4^{\circ} \mathrm{C}$ in accordance with the method of Ornstein et al. (pH 9.4). ${ }^{11)} \quad$ Protein band was stained with Amide Black $10 \mathrm{~B}$.

Estimation of molecular weight by gel filtration. The molecular weight of the enzyme was determined by gel filtration as described by Andrews. ${ }^{12)}$

\section{RESULTS}

\section{Purification of LPCase}

Step 1. Desalting. The crude enzyme was desalted by gel filtration with Bio-gel $\mathrm{P}-10$.

\section{Step 2. First DEAE-Sephadex Column} Chromatography. The desalted solution was applied to a DEAE-Sephadex A-25 column (Fig. 1), LPCase activity was separated into three fractions. The most active fractions (No. $73 \sim 86$ ) were combined, and concentrated with collodion-bag. The concentrated solution was dialyzed against $0.05 \mathrm{M}$ Tris- $\mathrm{HCl}$ buffer, $\mathrm{pH} 7.3$.

Step 3. Second DEAE-Sephadex Column Chromatography. The dialyzed solution was rechromatographed on a DEAE-Sephadex A-25 column. The active fractions were combined, and concentrated with collodion-bag. The concentrated solution was dialyzed against $10 \mathrm{~mm}$ phosphate buffer, $\mathrm{pH} 7.1$.

Step 4. Hydroxylapatite Column Chromatography. The dialyzed solution was applied to a hydroxylapatite column (Fig. 2). The activity was eluted at $50 \mathrm{~mm}$ and $100 \mathrm{~mm}$ 


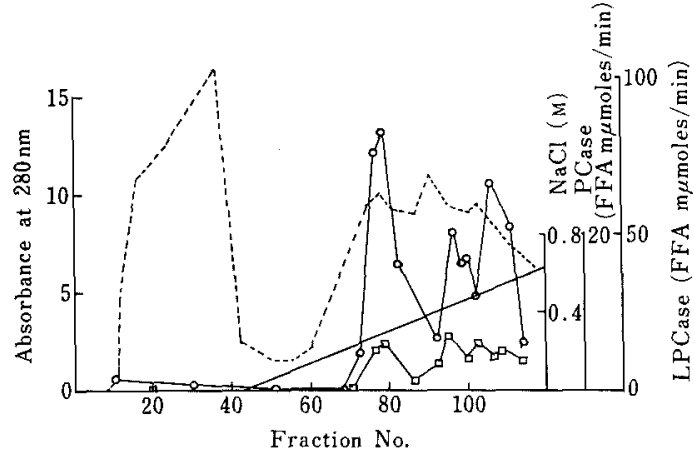

FIG. 1. DEAE-Sephadex Column Chromatography of LPCase from C. centrifugum.

Desalted enzyme solution $(320 \mathrm{ml}, 6.72 \mathrm{~g}$ protein) was applied to a DEAE-Sephadex A-25 column $(2.6 \times 36 \mathrm{~cm})$, which was equilibrated with $0.05 \mathrm{M}$ Tris$\mathrm{HCl}$ buffer, $\mathrm{pH} 7.3$. The elution, at a rate of $30 \mathrm{ml} /$ $\mathrm{hr}$, was carried out with a linear gradient of $\mathrm{NaCl}$ concentration from zero to $0.8 \mathrm{M}$ in the same buffer, and $10 \mathrm{ml}$ fractions were collected.

--.--, absorbance at $280 \mathrm{~nm}$; O-O, LPCase activity; $\square-\square$, PCase activity; $\longrightarrow, \mathrm{NaCl}$ concentration.

buffer. The active fractions were concentrated and named $50 \mathrm{~mm}$ Frn. and $100 \mathrm{~mm}$ Frn., respectively. After concentration with collodion-bag, these fractions were preserved at $-20^{\circ} \mathrm{C}$.

The results of purification by above procedures are summarized in Table $I$. The $50 \mathrm{~mm}$ Frn. and $100 \mathrm{~mm}$ Frn. showed 37- and 92-fold increases in specific activity, respectively. The $100 \mathrm{~mm}$ Frn. was used for the investigation of various properties described below except for the estimation of molecular weight. The hydrolysis reaction showed a linear rate up to at least $10 \mathrm{~min}$ incubation by the standard assay method.

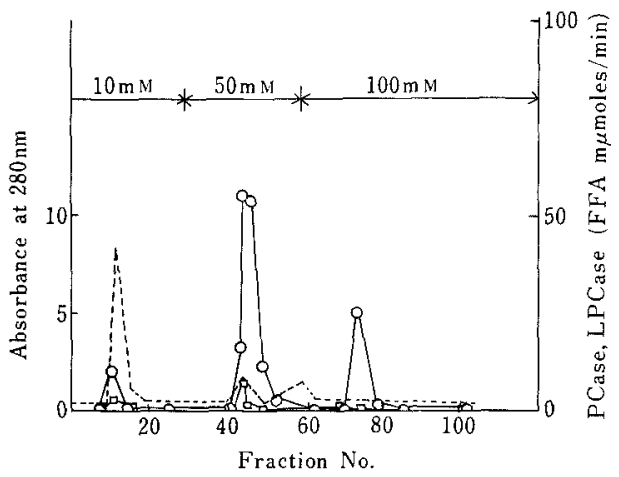

FIG. 2. Hydroxylapatite Column Chromatography of LPCase.

The dialyzed solution ( $8 \mathrm{ml}, 132 \mathrm{mg}$ protein) from the second DEAE-Sephadex (No. $51 \sim 57)$ was applied to a hydroxylapatite column $(2.6 \times 10 \mathrm{~cm})$, which was consisted of hydroxylapatite and cellulose $(1: 1, \mathrm{v} / \mathrm{v})$, and was equilibrated with $10 \mathrm{~mm}$ phosphate buffer, pH 7.1. The elution, at a rate of $35 \mathrm{ml} / \mathrm{hr}$, was carried out with a stepwise increase in buffer concentration $(10,50$ and $100 \mathrm{~mm})$ and $5 \mathrm{ml}$ fractions were collected. -..--, absorbance at $280 \mathrm{~nm}$; $-\mathrm{O}, \mathrm{LPC}$ ase activity; $\square-\square$, PCase activity.

\section{Homogeneity of purified enzyme}

Homogeneities of both fractions were examined by disc electrophoresis ( $\mathrm{pH}$ 9.4). The $50 \mathrm{~mm}$ Frn. had two LPCase components, and $100 \mathrm{~mm}$ Frn. had one (Fig. 3-(a) and (b)). The LPCase component of $50 \mathrm{~mm}$ Frn. (active fraction B in Fig. 3-(a)) was found a little contaminated with PCase activity.

\section{Estimation of molecular weight}

The molecular weight of LPCase $(50 \mathrm{~mm}$ Frn.: active fraction $\mathrm{A}$ in Fig. 3-(a)), determined by gel filtration with Sephadex G-200 (Fig. 4), was estimated to be about 130,000 .

Table I. Summary of the Purification of Lysophospholipase Produced by C. centrifugum

\begin{tabular}{|c|c|c|c|c|c|c|c|}
\hline \multirow[t]{2}{*}{ Procedure } & \multirow[t]{2}{*}{$\begin{array}{l}\text { Protein } \\
\text { (mg) }\end{array}$} & \multicolumn{2}{|c|}{$\begin{array}{c}\text { Activity } \\
\text { (units) }\end{array}$} & \multicolumn{2}{|c|}{$\begin{array}{l}\text { Specific activity } \\
\text { (units/mg) }\end{array}$} & \multicolumn{2}{|c|}{ Recovery } \\
\hline & & LPCase & PCase & LPCase & PCase & LPCase & PCase \\
\hline $\begin{array}{l}\text { Desalted solution of } \\
\text { lyophilized protein of } \\
\left(\mathrm{NH}_{4}\right)_{2} \mathrm{SO}_{4} \text { ppt. }(100 \% \text { satn. })\end{array}$ & 6720 & 4964.4 & 5325.6 & 0.74 & 0.79 & 100 & 100 \\
\hline 1st DEAE-Sephadex & 875 & 1632.8 & 430.5 & 1.86 & 0.49 & 32.9 & 8.1 \\
\hline 2nd DEAE-Sephadex & 131.6 & 781.3 & 109.6 & 5.55 & 0.83 & 14.7 & 2.1 \\
\hline Hydroxylapatite & & & & & & & \\
\hline $50 \mathrm{~mm}$ Frn. & 11.6 & 313.9 & 39.4 & 27.18 & 3.41 & 6.35 & 0.74 \\
\hline $100 \mathrm{~mm}$ Frn. & 1.3 & 91.1 & 0.0 & 68.00 & 0.00 & 1.83 & 0.00 \\
\hline
\end{tabular}




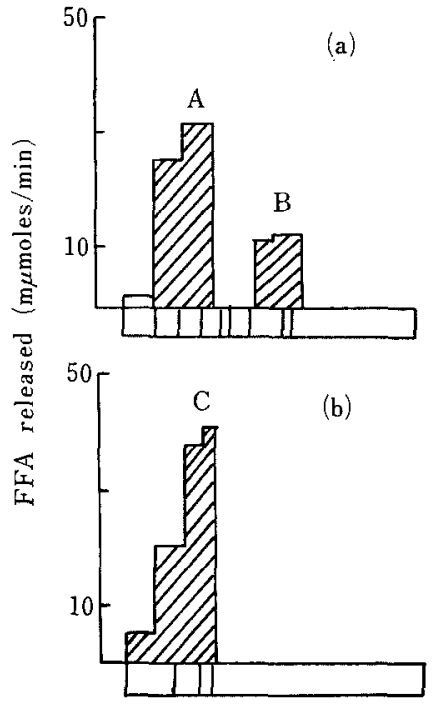

FIG. 3. Disc Electrophoresis of LPCase.

About 30 50 $\mu \mathrm{g}$ of the purified enzyme was subjected to electrophoresis at $\mathrm{pH}$ 9.4. See the text for experimental details. (a) and (b) are the patterns of disc electrophoresis of $50 \mathrm{~mm}$ Frn. and $100 \mathrm{~mm}$ Frn., respectively.

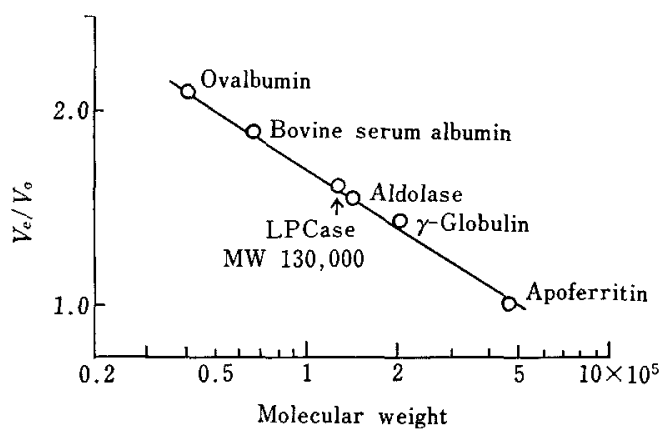

FIG. 4. Estimation of Molecular Weight of LPCase by Gel Filtration.

Chromatography was carried out on a Sephadex G200 column $(1.5 \times 95 \mathrm{~cm})$ with $0.05 \mathrm{M}$ Tris- $\mathrm{HCl}$ buffer, pH 7.4, containing $0.1 \mathrm{M} \mathrm{KCl}$ after the column had been equilibrated with the same buffer. $V_{\theta}$, the elution volume; $V_{o}$, the void volume.

\section{Isoelectric point}

$50 \mathrm{~mm}$ Frn. (active fraction A in Fig. 3-(a)) and $100 \mathrm{~mm}$ Frn. had the same isoelectric point at about $\mathrm{pH} 3.9$.

\section{Optimal pH of LPCase}

As shown in Fig. 5, the $\mathrm{pH}$ optimum of LPCase activity was found to be $3.5 \sim 5.0$.

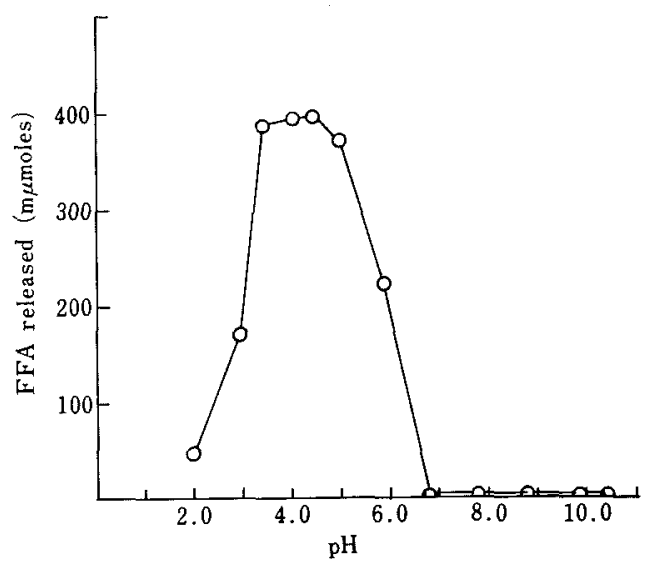

FIG. 5. Effect of $\mathrm{pH}$ on LPCase Activity.

The enzyme activity was measured by the standard assay method with enzyme preparation I. Buffers used were: $0.1 \mathrm{M}$ glycine- $\mathrm{HCl}$ buffer containing $0.1 \mathrm{M}$ $\mathrm{NaCl}(\mathrm{pH} 2.0 \sim 2.9), 0.1 \mathrm{M}$ acetate buffer (pH 3.4 5.8 ), $0.03 \mathrm{M}$ phosphate buffer ( $\mathrm{pH} 6.8 \sim 7.9$ ) and $0.1 \mathrm{M}$ glycine-NaOH buffer containing $0.1 \mathrm{M} \mathrm{NaCl}(\mathrm{pH} 8.8 \sim$ 10.6).

\section{$p H$ stability}

The stability of LPCase in solutions of various $\mathrm{pH}$ values is shown in Fig. 6 . The

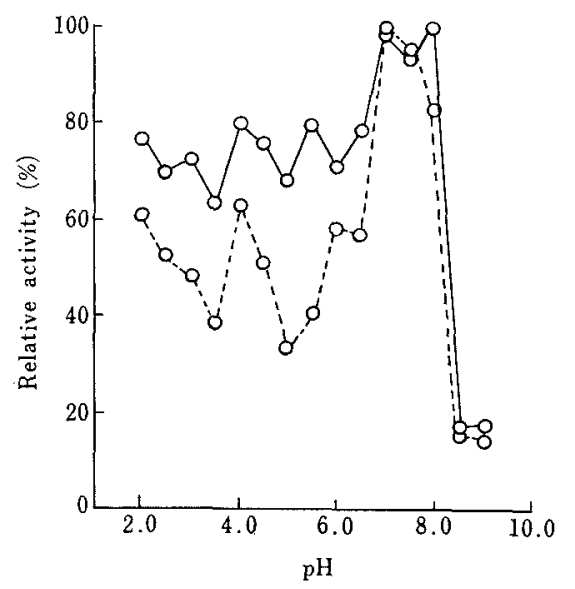

FIG. 6. Effect of $\mathrm{pH}$ on the Stability of LPCase.

The enzyme solution was incubated at each $\mathrm{pH}$ value from 2.0 to 9.0 for 47 and $100 \mathrm{hr}$ at $4^{\circ} \mathrm{C}$, and the remaining activities were assayed. Buffers used were: $0.1 \mathrm{M}$ sodium acetate-HCl buffer $(\mathrm{pH} 2.0 \sim 3.0), 0.1 \mathrm{M}$ acetate buffer (pH 3.5 5.0) $0.05 \mathrm{M}$ phosphate buffer $(\mathrm{pH} 5.5 \sim 8.0)$ and $0.05 \mathrm{M}$ Tris- $\mathrm{HCl}$ buffer $(\mathrm{pH} 8.5 \sim$ 9.0).

$\mathrm{O}-\mathrm{O}$, incubation for $47 \mathrm{hr}$; $\mathrm{O}--\mathrm{O}$, incubation for $100 \mathrm{hr}$. 
enzyme was most stable in the $\mathrm{pH}$ range of 7.0 to 8.0 , and more stable on the acidic than on the alkaline side.

\section{Thermal stability}

The enzyme was stable up to $35^{\circ} \mathrm{C}$ at $\mathrm{pH} 7.0$, but it rapidly lost its activity at $45^{\circ} \mathrm{C}$. Up to $40^{\circ} \mathrm{C}$, the enzyme was more stable at $\mathrm{pH} 7.0$ than at $\mathrm{pH} 4.0$, but from 40 to $60^{\circ} \mathrm{C}$, it was more stable at $\mathrm{pH} 4.0$ (Fig. 7).

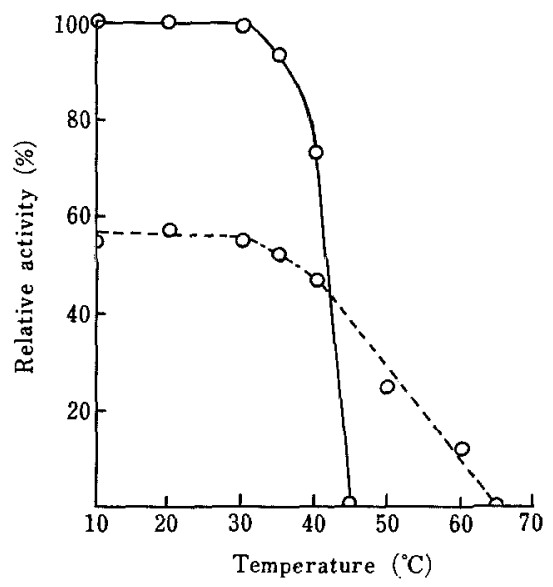

FIG. 7. Thermal Stability of LPCase.

The enzyme solution was incubated at various temperatures for $15 \mathrm{~min}$ at $\mathrm{pH} 4.0$ and 7.0 , and the remaining activity was assayed.

$\bigcirc-0$, pH 7.0; О---, pH 4.0.

\section{Effect of metal ions}

The effect of various metal ions on LPCase activity is shown in Table II. None of the metal ions stimulated LPCase activity. $\mathrm{Fe}^{3+}$, $\mathrm{Hg}^{2+}$ and $\mathrm{Al}^{3+}$ inhibited $100 \%, 46 \%$ and $32 \%$ of LPCase activity, respectively.

\section{Effect of organic solvents}

Enzyme activity was measured by incubation with various organic solvents (Table III). Ethanol, methanol, 1-propanol, 2-propanol and glycerol at a final concentration of $10 \%$ stimulated LPCase activity, but ethanol at $30 \%$ inhibited the activity. When the enzyme solution was incubated with $5 \sim 20 \%$ ethyl ether, enzyme activity was stimulated by $20 \sim$ $30 \%$.

\section{Effect of reagents}

The effect of various reagents on LPCase
Table II. Effect of Metal Ions on LPCASE ACTIVITY

The enzyme activity was determined by the standard assay method with enzyme preparation I, except that $10 \mathrm{~mm}$ of one or another of the indicated reagents was added before the reaction. The activity is expressed in percentage of the activity level in the absence of metal salts. $\mathrm{Ag}^{+}$was used as the nitrate form and the other metal ions were used as the chloride form.

\begin{tabular}{|c|c|}
\hline Metal ions (10 mM) & Activity $(\%)$ \\
\hline None & 100 \\
\hline $\mathrm{Mg}^{2+}$ & 93 \\
\hline $\mathrm{Ca}^{2+}$ & 93 \\
\hline $\mathrm{Ba}^{2+}$ & 98 \\
\hline $\mathrm{Al}^{3+}$ & 68 \\
\hline $\mathrm{Mn}^{2+}$ & 102 \\
\hline $\mathrm{Fe}^{2+a)}$ & 101 \\
\hline $\mathrm{Fe}^{3+}$ & 3 \\
\hline $\mathrm{Co}^{2+}$ & 98 \\
\hline $\mathrm{Ni}^{2+}$ & 94 \\
\hline $\mathrm{Cu}^{2+}$ & 94 \\
\hline $\mathrm{Zn}^{2+}$ & 92 \\
\hline $\mathrm{Ag}^{+}$ & 101 \\
\hline $\mathrm{Hg}^{2+}$ & 54 \\
\hline a) $\mathrm{Fe}^{2+}$ was prepared & $\mathrm{Cl}_{2} \cdot n \mathrm{H}_{2} \mathrm{O}(n=6)$ \\
\hline
\end{tabular}

The enzyme activities were determined by the standard assay method with enzyme preparation I, except that one or another of the listed organic solvents at the indicated concentration was added before the reaction. When the volume of organic solvent had to be increased, the equivalent volume of acetate buffer was decreased.

\begin{tabular}{ccc}
\hline Organic solvents & Conc. (\%) & Activity (\%) \\
\hline None & - & 100 \\
Ethanol & 10 & 161 \\
$"$ & 20 & 153 \\
$"$ & 30 & 41 \\
Methanol & 10 & 200 \\
1-Propanol & 10 & 142 \\
2-Propanol & 10 & 196 \\
Glycerol & 10 & 124 \\
\hline
\end{tabular}

activity is shown in Table IV. Despite the inhibition of enzymatic activity by $\mathrm{Hg}^{2+}$, LPCase was not inhibited by specific $\mathrm{SH}$ reagents. Among imidazole group reagents, diethylpyrocarbonate did not inhibit LPCase activity, but diazobenzen $p$-sulfonic acid did inhibit $89 \%$ of it at $10 \mathrm{mM}$. N-Bromosuccinimide exhibited an inhibitory effect of $100 \%$ 
Table IV. EFFect of Vartous Reagents on LPCASE ACTIVITY

The enzyme was incubated with each reagent in $0.05 \mathrm{M}$ phosphate buffer, $\mathrm{pH} 7.0$, at $30^{\circ} \mathrm{C}$ for $30 \mathrm{~min}$, and the residual activity was assayed. When diethylpyrocarbonate was used, the enzyme solution was incubated in $0.05 \mathrm{M}$ phosphate buffer, $\mathrm{pH} 7.0$, containing ethanol at $0^{\circ} \mathrm{C}$ for $30 \mathrm{~min}$. When disopropylfluorophosphate and phenylmethylfluoride were used, the enzyme solution was incubated in $0.1 \mathrm{M}$ acetate buffer, $\mathrm{pH} 4.0$, containing isopropanol at $0^{\circ} \mathrm{C}$ for $60 \mathrm{~min}$.

\begin{tabular}{lrr}
\hline \multicolumn{1}{c}{ Addition } & $\begin{array}{c}\text { Concentration } \\
(\mathrm{mM})\end{array}$ & $\begin{array}{c}\text { Inhibition } \\
(\%)\end{array}$ \\
\hline N-Ethylmaleimide & 10 & 3 \\
Dithionitrobenzoic acid & 1 & 4 \\
$\begin{array}{l}p \text {-Chloromercuribenzoate } \\
\text { Iodoacetamide }\end{array}$ & 1 & 0 \\
Monoiodoacetic acid & 10 & 5 \\
N-Acetylimidazole & 10 & 0 \\
1, 2-Cyclohexanedione & 10 & 0 \\
Diethylpyrocarbonate & 10 & 0 \\
Diazobenzene $p$-sulfonic & 10 & 0 \\
$\quad$ acid & 10 & 89 \\
N-Bromosuccinimide & 1 & 100 \\
Diisopropyl- & & 19 \\
$\quad$ fluorophosphate & 1 & 7 \\
Phenylmethyl- & & \\
$\quad$ sulfonylfuoride & 1 & \\
\hline
\end{tabular}

at $1 \mathrm{~mm}$. Among serine-OH group reagents, diisopropylfluorophosphate inhibited LPCase by $19 \%$ at $1 \mathrm{~mm}$ concentration.

\section{Substrate specificity}

Apparent Michaelis constants $(\mathrm{Km})$ of LPCase activity for (u)-[ $\left.{ }^{14} \mathrm{C}\right]-1$-acyl-LPC, 1$\left[{ }^{14} \mathrm{C}\right]$-palmitoyl-LPC and $1-\left[{ }^{14} \mathrm{C}\right]$-oleoyl-LPC were calculated from Lineweaver-Burk plots to be $0.35,0.16$ and $0.09 \mathrm{~mm}$, and $V_{\max }$ were $79.1,58.7$ and $52.1 \mu$ moles/min per $\mathrm{mg}$ of protein, respectively, as shown in Fig. 8 . The Lineweaver-Burk plots for $1-\left[{ }^{14} \mathrm{C}\right]$-palmitoylLPC and 1-[ $\left[{ }^{14} \mathrm{C}\right]$-oleoyl-LPC were broken at $0.25 \mathrm{~mm}$ and $0.4 \mathrm{~mm}$, respectively. Under the influence of $10 \%$ ethanol, their Michaelis constants were $0.36,0.07$ and $0.07 \mathrm{mM}$, and $V_{\max }$ were $131.6,106.4$ and $96.2 \mu$ moles $/ \mathrm{min}$ per $\mathrm{mg}$ of protein, respectively. In this case, the Lineweaver-Burk plot for $(\mathrm{u})-\left[{ }^{14} \mathrm{C}\right]-1$-acylLPC was also broken at $0.34 \mathrm{~mm}$, and the break points for $1-\left[{ }^{14} \mathrm{C}\right]$-palmitoyl-LPC and
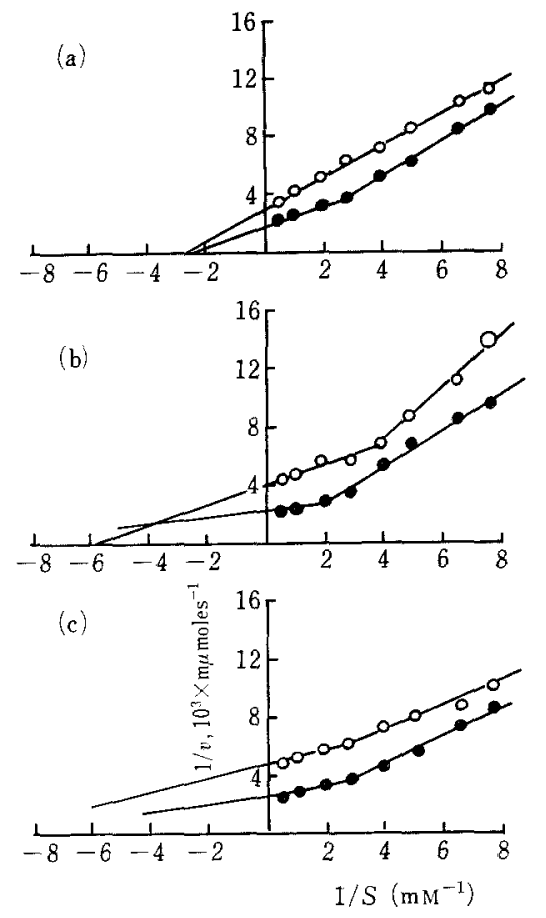

FIG. 8. Effect of LPC Concentration on LPCase Activity.

The enzyme activities were determined by standard methods. (a) (u)- $\left[{ }^{14} \mathrm{C}\right]-1$-acyl-LPC, (b) $1-\left[{ }^{14} \mathrm{C}\right]$-palmitoyl-LPC, (c) $1-\left[{ }^{14} \mathrm{C}\right]-o l e o y l-L P C . \quad \mathrm{O}-\mathrm{O}$, without ethanol; - - with $10 \%$ ethanol.

\section{1-[ $\left[{ }^{4} \mathrm{C}\right]$-oleoyl-LPC rose.}

Mono-, di- and tripalmitin were used as substrates for lipase activity. These substrates were used as a dispersed solution by a ultrasonication or with $0.1 \%$ Triton $\mathrm{X}-100$ or $10 \%$ ethyl ether. The enzyme solution was incubated with $2 \mathrm{mM}$ substrates in acetate buffer, $\mathrm{pH} 4.0$, at $30^{\circ} \mathrm{C}$ for $30 \mathrm{~min}$, but these substrates were not hydrolyzed.

PC was used as substrate for PCase activity. The enzyme was incubated with an ultrasonic dispersion of $\mathrm{PC}(1 \mathrm{mM})$ in the acetate buffer, pH 4.0 , at $30^{\circ} \mathrm{C}$ for $30 \mathrm{~min}$, but PC was not hydrolyzed.

\section{Effect of bovine serum albumin}

The effect of bovine serum albumin on LPCase activity was investigated, with (u)$\left[{ }^{14} \mathrm{C}\right]-1$-acyl-LPC, 1-[14 $\left.\mathrm{C}\right]$-palmitoyl-LPC and 1$\left[{ }^{14} \mathrm{C}\right]$-oleoyl-LPC used as substrates. LPCase 
activity was not affected by bovine serum albumin below $500 \mu \mathrm{g} / \mathrm{ml}$, regardless of the kind of substrate.

\section{Effect of phosphatidylcholine}

The enzyme solution was incubated with $1 \mathrm{~mm}$ labeled LPC and various concentrations of PC. As shown in Fig. 9, regardless of the

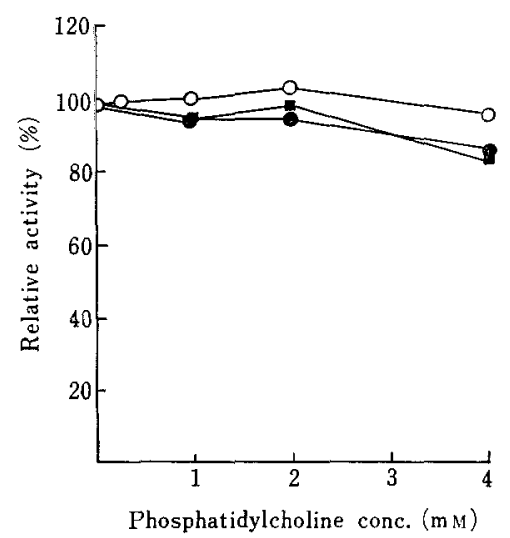

Fig. 9. Effect of Phosphatidylcholine on LPCase Activity.

The enzyme activities were determined by standard methods except that varying amounts of ultrasonic dispersion of PC were added before the reaction.

Substrates: $\bigcirc-O$, (u)-[ $\left.{ }^{14} \mathrm{C}\right]-1$-acyl-LPC; $-0,1$ $\left[{ }^{14} \mathrm{C}\right]$-palmitoyl-LPC; $\mathbf{n}-\mathbf{E}, 1-\left[{ }^{14} \mathrm{C}\right]$-oleoyl-LPC.

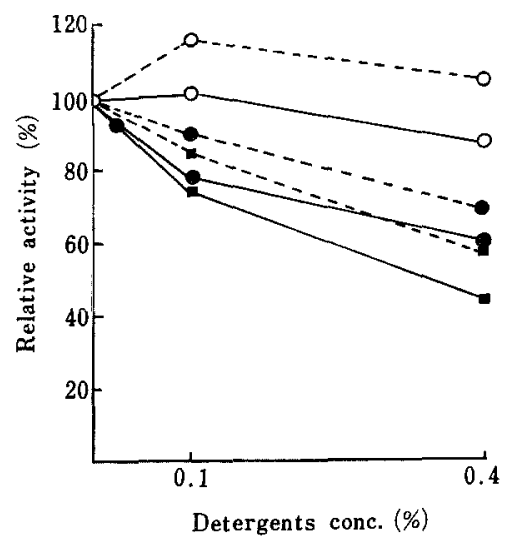

FIG. 10. Effect of Detergents on LPCase Activity. The enzyme activities were determined by standard methods except that varying concentrations of detergents were added before the reaction.

Substrates: $\bigcirc-O$, (u)-[14C]-1-acyl-LPC; - -1 , $\left[{ }^{14} \mathrm{C}\right]$-palmitoyl-LPC; $\mathbf{\square - \mathbf { 0 }}, 1-\left[{ }^{[4} \mathrm{C}\right]$-oleoyl-LPC. Detergents: ------, Tween 80 ; _ kind of substrate, LPCase activity was little affected by PC.

\section{Effect of detergents}

The effect of detergents was investigated with various substrates as shown in Fig. 10. When (u)-[ $\left.{ }^{14} \mathrm{C}\right]-1$-acyl-LPC was used as substrate, LPCase activity was stimulated by Triton X-100 at a concentration of $0.1 \%$ $(\mathrm{w} / \mathrm{v})$ and by Tween 80 at 0.1 and $0.4 \%$. However, when 1-[ $\left[{ }^{4} \mathrm{C}\right]$-palmitoyl-LPC and 1$\left[{ }^{14} \mathrm{C}\right]$-oleoyl-LPC were used as substrates, LPCase activity was inhibited by both detergents at all concentrations tested.

\section{DISCUSSION}

In the hydroxylapatite column chromatography, the active fraction was divided into $50 \mathrm{~mm}$ Frn. and $100 \mathrm{~mm}$ Frn. However, the properties of these fractions with respect to the pattern of disc electrophoresis, optimal $\mathrm{pH}$, isoelectric point, effects of stimulators and inhibitors and $\mathrm{Km}$ for LPC were similar, and we could not find any difference. The molecular weight of LPCase was determined with $50 \mathrm{~mm}$ Frn.

LPCase produced by $C$. centrifugum is similar to that of a mold, Penicilium notatum, ${ }^{13)}$ in acidic $\mathrm{pH}$ optimum $(3.5 \sim 5.0)$, isoelectric point (pH 3.9), molecular weight $(130,000)$ and thermal instability.

Inhibition by histidine reagents was observed with LPCase from cod muscle, ${ }^{14)}$ and diisopropylfluorophosphate inhibition was observed with bovine pancreas, ${ }^{15)}$ but no inhibition by N-bromosuccinimide has been reported.

This enzyme differed from those of the bovine pancreas ${ }^{15}$ and $E$. coli ${ }^{16}$ ) enzymes which show the lipase activity. Nor did it exhibit phospholipase $\mathbf{B}$ activity which was observed with $P$. notatum. ${ }^{13}$ )

LPCase activity of $C$. centrifugum was not affected by bovine serum albumin. This result is similar to that observed with the LPCase of Culex pipiens fatigans. ${ }^{17)}$

The inhibition of LPCase by PC, which was observed with bovine pancreas ${ }^{15)}$ and mos- 
quito, ${ }^{17)}$ was not observed with $C$. centrifugum.

The sensitivity of LPCase from $C$. centrifugum to stimulation by various organic solvents and detergents characteristically distinguishes this enzyme from other general LPCases.

The appearance of a break point and the difference of its values with each three substrates which is different in its fatty acid composition, in Lineweaver-Burk plots mean that the micellar form gives a better substrate for LPCase than the monomolecular form, and that each LPC has its own micellar structure determined by its fatty acid composition. Under the influence of $10 \%$ ethanol, though $\mathrm{Km}$ did not change, $V_{\max }$ was greater than in the absence of ethanol. This result suggests that ethanol mainly affects the enzyme rather than the substrate in the hydrolysis of LPC. (u)- $\left[{ }^{14} \mathrm{C}\right]-1-A c y l-L P C$ was hydrolysed more rapidly than $1-\left[{ }^{14} \mathrm{C}\right]$-palmitoyl-LPC and $1-\left[{ }^{14} \mathrm{C}\right]-$ oleoyl-LPC. The fatty acid composition of a carrier LPC of $(\mathrm{u})-\left[{ }^{14} \mathrm{C}\right]-1$-acyl-LPC is shown in Table V. This indicates that the mixed composition of fatty acids of a carrier LPC gives a good micellar structure for this enzyme to (u) $-\left[{ }^{14} \mathrm{C}\right]-1$-acyl-LPC.

Table V. Molecular Species of LPC

\begin{tabular}{clr}
\hline $\begin{array}{c}\text { Carbon } \\
\text { number }\end{array}$ & C-1 & Fatty acid $(\%)$ \\
\hline 16 & 16:0 (Palmitic acid) & 79.3 \\
18 & $18: 0$ (Stearic acid) & 16.6 \\
& $18: 1$ (Oleic acid) & 4.1 \\
\hline
\end{tabular}

In the experiment concerning the effect of detergents on LPCase activity, the change of substrate from (u) $-\left[{ }^{14} \mathrm{C}\right]-1$-acyl-LPC to $1-\left[{ }^{14} \mathrm{C}\right]-$ palmitoyl-LPC or $1-\left[{ }^{14} \mathrm{C}\right]$-oleoyl-LPC was observed to reverse the effect of detergents. This result indicates that the interaction of LPC and detergents is affected by the fatty acid composition of LPC, and (u)- $\left[{ }^{14} \mathrm{C}\right]-1$-acyl-LPC that has a mixed composition of fatty acids can be more favorable to LPCase.

Acknowledgement. A part of this work was supported by a grant for scientific research from the Ministry of Education of Japan. The authors wish to thank Kyoto Research Laboratory, Marukin Shoyu Co., Ltd., Uji, for its kind supply of a source of fungus and advice on culture and treatment of culture broth.

\section{REFERENCES}

1) K. Hasegawa, M. Murata, T. Suzuki and A. Takigawa, Agric. Biol. Chem., 37, 2169 (1973).

2) M. C. Pangborn, J. Biol. Chem., 188, 471 (1950).

3) D. J. Hanahan, ibid., 195, 199 (1952).

4) E. G. Bligh and W. J. Dyer, Can. J. Biochem. Physiol., 37, 911 (1959).

5) W. G. Duncombe, Biochem. J., 88, 7 (1963).

6) K. Satouchi, T. Mori and S. Matsushita, Agric. Biol. Chem., 38, 97 (1974).

7) K. Itaya and M. Ui, J. Lipid Res., 6, 16 (1965).

8) E. Doi and C. Ohtsuru, Agric. Biol. Chem., 38, 1749 (1974).

9) O. Vesterberg, "Methods in Enzymology," Vol. XXII, ed. by S. P. Colowick and N. O. Kaplan, Academic Press Inc., New York and London, 1971, p. 389.

10) O. H. Lowry, N. J. Rosenbrough, A. L. Forr and R. J. Randall, J. Biol. Chem., 193, 263 (1951).

11) L. Ornstein and B. J. Davis, Ann. N. Y. Acad. Sci., 121, 321, 404 (1964).

12) P. Andrews, Biochem. J., 96, 595 (1965).

13) N. Kawasaki and K. Saito, Biochim. Biophys. Acta, 296, 426 (1973).

14) M. Yurkowski and H. Brockerhoff, J. Fish. Res. Bd. Can., 22, 643 (1965).

15) H. van den Bosch, A. J. Aarsman, J. G. N. De Jong and L. L. M. van Deenen, Biochim. Biophys. Acta, 296, 94 (1973).

16) O. Doi and S. Nojima, J. Biol. Chem., 250, 5208 (1975).

17) R. H. Rao and D. Subrahmanyan, J. Lipid Res., 10, 636 (1969). 